\title{
A CSALÁD SZEREPE A PÁLYAVÁLASZTÁSBAN
}

\section{Szerző:}

Olteanu Lucián Líviusz (Drs)

Eszterházy Károly Egyetem

Szerző e-mail címe:

luciolteanu@gmail.com

\section{Lektorok:}

Szabóné Balogh Ágota (PhD)

Gál Ferenc Főiskola

Lestyán Erzsébet (PhD)

Gál Ferenc Főiskola

...és további két anonim lektor

\begin{abstract}
Absztrakt
Számos pályafejlődéssel foglalkozó tanulmány a pályaválasztással kapcsolatos döntésképtelenséget - a hivatásválasztással kapcsolatos döntéshozási képesség hiányát - az interperszonális és intraperszonális folyamatokkal hozza összefüggésbe. A jelen tanulmány két komponensre koncentrál: a kontextuális (pl. szülők, baráti társaság) és az individuális komponensekre. Ez azonosítja be az egyén és a kontextus között, valamint ezeken belül lejátszódott folyamatok visszatérő interakciójának jelenlétét. Az eddigi kutatás megmutatja, hogy a szülőkhöz, testvérekhez és kortársakhoz füződő viszony hogyan befolyásolja azt, hogy az adott személy miként hozza meg pályaválasztással kapcsolatos döntését, valamint hogy mennyire tart ki e döntése mellett, segítségére lehet a tanácsadóknak abban, hogy megtervezzék a pályatervezést célzó intervenciót.
\end{abstract}

Kulcsszavak: pszichológiai tanácsadás, tréning, OxIPO model, családi hatások

Diszciplinák: pszichológia, pszichológiai tanácsadás

\section{Abstract}

\section{THE FAMILY'S ROLE IN CAREERCHOICE}

Numerous career-development studies have linked career indecision - lack of career decision-making ability - to interpersonal and intrapersonal processes. This study focuses on two components: contextual (eg, parents, friends) and individual components. It identifies the presence of recurrent interactions between the individual and the context and within them. Research to date shows how relationships with parents, siblings, and peers influence how a person makes a career choice, and how he or she can help guide counselors in planning career planning interventions. 
Keywords: career decision-making difficulties, training, OxIPO model, familly influences

Disciplines: psychology, pedagogy

Olteanu Lucián Líviusz (2019): A család szerepe a pályaválasztásban. OxIPO - interdiszciplináris tudományos folyóirat, 2019/4, 23-35. doi: 10.35405/OXIPO.2019.4.23

A pályaválasztással kapcsolatos inter- és intraperszonális komponenseket gyakran összefüggésbe hozzák döntésképtelenséggel. A közelmúltig csak kevés kutatás foglalkozott a fent említett területtel, és csak annyit állapítottak meg, hogy létezik ilyen kapcsolat. (Leong és Chervinko, 1996).

A hivatás kiválasztása az első olyan fontos és független komplex döntés, amelyet egy fiatal meghoz az életében. A döntés meghozatala során nem tud még az élettapasztalatára hagyatkozni, mivel az majd csak a későbbi évek során alakul ki, egyelőre csak a saját elképzelésére, hogy milyen lesz a jövője a jövô társadalmában. Minél tudatosabban és tisztábban látják a fiatalok a jövőjüket, annál felelősségteljesebben tudnak a jelenben dönteni (Walsh és Osipow, 1988). Az OxIPOmodell aspektusainak megfelelően a pályaválasztási döntés is egy output, amely az inputok (ismeretek, élmények, tapasztalatok) feldolgozását követően létrejövő szellemi termék (Mező és Mező, 2019).

A családok - különösen a szülők - erôsen hatnak a serdülő gyermek karrierfejlődésére (Whiston és Keller, 2007).
Elég csak arra gondolnunk, hogy miként ért egyet a szülő és a serdülő a karriercélok és -aspirációk tekintetében. Ki mit preferál, és főként, hogy mennyire kommunikál erről szülő és gyermeke. Igazolható, hogy a karrierfejlődés szempontjából pozitívabb az egyezés a célokban, míg a diszkrepancia negatív hatású (Kissné és Mogyorósy-Révész, 2017).

A pályaválasztás is egy ilyen folyamat az ezzel járó döntés rendkívül komplex. A rossz pályaválasztási döntések az egyének és a társadalomnak is jelentős motivációs és gazdasági kárt okoz. A pályaválasztási tanácsadó intézmények nemcsak karrier tanácsadást kínálnak, hanem egy sor tesztet, valamint információs anyagokat és képzési programokat is, hogy egyengessék az emberek pályaválasztással kapcsolatos döntéseit, ezzel pedig elősegítsék a később megbánt döntések számának csökkenését.

A karrierválasztást egyes családok nehézségként élik meg, amit a sikeres jövőért küzdő fiatalnak el kell szenvednie, hogy a munkanélküliséget elkerülje a jövőben. A pályaválasztásra, foglalkozás- 
választásra jelentős hatást gyakorol a testvérek, szülők, rokonok, elérhető ba-rátok példája. A családi „mikrokörnyezet” jelentős befolyásoló hatással bír (Csákó, 1998). Ezt a hatást a „közvélemény” és a tárgyszerű ismeretek is nehezen ellensúlyozzák. A továbbtanulási döntés hátterében további fontos szempont a család anyagi teherbíró képessége, amely a választás lehetőségeit jelentős mértékben korlátozza.

\section{A család szerepe a pályaválasztásban}

A szülői háttér és a szülők igyekezete a gyermek fejlesztésére jelentősen hatnak a kamasz karriervágyaira és továbbtanulási terveire (Perry, Liu és Pabian, 2010). Az iskolai pályaválasztási tanácsadás egy olyan típusú komplex tevékenység, amely ötvözi a nevelési tanácsadást, a szakmai orientációt és a karrier tanácsadást. Ezáltal minden olyan tevékenységet egy fogalomba tudunk sűríteni, amely felkészíti a fiatalt a jövőbeli szakmájára, életútjára. Az iskolai pályaválasztási tanácsadás kiemeli az iskola fontos szerepét a jövő generációjának az életre való felkészítésében. A hivatás kiválasztása az az aspektus, amely kiteljesíti az oktatás (morális, intellektuális és esztétikai fejlődés) komplex folyamatát (Chelcea, 1981).

A pályaválasztási tanácsadás egyik fő célja, hogy teljes körūen elősegítse a pályaválasztási folyamatot a tanácsadást kérő személy és családjának számára, valamint közelebbrôl, hogy segítsen neki megbir- kózni e folyamat során felmerülő nehézségekkel.

Ennek megfelelően a tanácsadást kérő személyek számára szükséges segítségnyújtás lényegi eleme azon egyedi nehézségek beazonosítása, amelyek meggátolják az egyéneket abban, hogy döntésre jussanak. A jelenleg jellemző pályaválasztási trend a széles körben alkalmazható képzettség és a biztonság keresésének igénye: magasan kvalifikált szakmák választása, vagy több, egymástól esetleg jelentősen eltérő foglalkozási területen szerzett szakmai képesítés. A fiatalok és szülők igénye, hogy diplomával, lehetôleg többfélével rendelkezzék a fiatal.

Ma egy olyan folytonosan változó világban élünk, ahol a jelen tudásának birtoklása nem jelent teljes garanciát a holnapra is. Ez azt jelenti, hogy amit egyszer megtanultunk, az nem biztos, hogy örök érvényű a jövőre nézve. Az elmúlt években teljesen megváltozott a felfogás arról is, hogy ki számít jó munkaerőnek. Régebben az számított kiváló munkaerőnek, aki egy munkahelyen töltötte el a teljes életét. Ma már alapkövetelménnyé vált az élethosszig tartó tanulás, a kellő rugalmasság.

Tudni kell váltani nemcsak munkahelyet, hanem szakmát, sőt pályát is. Nem véletlen az sem, hogy úgy tartják, a felsőoktatásban szerzett tudás öt év alatt elévül. Ha nem szerez valaki újabb diplomát, nem frissíti jelenlegi ismereteit, tíz év múlva 20\%-kal amortizálódhat a már megszerzett tudása (Földes, 2000). 
Az ember élete során számos társadalmi szerepet ,játszik el”. E szerepek közül talán az egyik legfontosabb a „szakma” szerepe. Ezen okból kifolyólag az ember énképe és identitástudata állandó összeköttetésben van e szerep tartalmával. Ez a tevékenység olyan intellektuális aktivitást tesz szükségessé, amely hozzájárul a személyiség formálásához, alakulásához.

A gimnázium a családok többségében még mindig úgy él, mint „parkolópálya”, a pályaválasztási döntés elodázásának eszköze. Kivételt képeznek azok a családok, amelyek határozott egyetemi továbbtanulási aspirációkkal küldik gimnáziumba gyermeküket. Azért, mert tudják, hogy mit akar. Ma a legtöbb megkérdezett szülő olyan erős és egyértelmű kapcsolatot lát a tanulmányi eredmény és az eséllyel megpályázható középiskolák között, amilyet korábbi vizsgálatok keretében nem tapasztaltak a kutatók.

A megismerés és a cselekvés két fó momentum az ember egyedi személyiségének kialakulásában. Mindent, amit az oktatási folyamat során átadnak, direkt vagy indirekt módon, tárgyiasulni fog az ember élete során folytatott tevékenységében. A pályaválasztás az élet bármely pillanatában bekövetkezhet, s mindenképp nagy hatása lesz az ember életére, legyen az kamasz, aki most választja ki a szakmáját, vagy egy felnőtt, aki munkahelyet változtat (Bandura, 1994).

A munka világának gyorsuló ütemú változása az egyének élete során végzett pályamódosításainak számát is megnövelte.
Ezen átmenetek során meghozott pályával kapcsolatos döntések minősége az egyén és a társadalom szempontjából is lényeges. A pályaválasztás azonban komplex folyamat. Vannak olyan emberek, akik könnyen hoznak ilyen döntéseket, legalábbis látszólag, másoknak nehézséget okoz, és sokan szaktanácsadóhoz fordulnak.

\section{Testvérek szerepe}

A testvéreket gyakran figyelmen kívül hagyják, mint társas kapcsolati biztonságot és támaszt nyújtó személyeket, amely kapcsolat ráadásul egész életén át fennmarad (Palladino Schultheiss és mtsai, 2002). A felnőtt testvérek különösen fontos támaszai és gondviselői lehetnek egymásnak számos területen és formában, függetlenül a szülőktől és a család egészétől. A testvérek a biztonságot és a szeretetet jelentik egymás számára (Cicirelli, 1995). Ezáltal járul hozzá a karrierfejlődéshez, hogy felismeri a folyamatban lévő döntési folyamatot a személy minden egyes életszakaszában bekövetkezett fejlődése közben. Ezt úgy kell elképzelni, hogy az egyén és a rá jellemző rendszerek nem lineáris folyamata szélesebb időbeli szerkezetként halad előre az időben. Figyelembe veszi a múlt-, jelen- és jövőbeni befolyásoló tényezőket. A Palladino Schultheiss 2002ben írt tanulmány szerint a testvéri kapcsolatok egyéni pályaútra gyakorolt hatása megerősíti azt a feltételezését, miszerint 
folyamatos változás és visszahatás zajlik. A tanulmány a szociális támasz 4 dimenzióját vizsgálta: érzelmi támasz, szociális integráció, önbecsülési támasz és információs támasz. A résztvevôk különbséget tettek a testvérek között általában, illetve a számukra legfontosabb testvér között. A tanulmány rámutatott, hogy a legfontosabb testvér a szociális támasz mind a négy aspektusára befolyással volt. Csak az érzelmi támasz volt az a dimenzió, ahol a többi testvér is hatást gyakorolt az egyénre. A kapott érzelmi támaszt érzelmi közelséggel és bátorítással azonosították. A résztvevők a szociális integráció testvéri támogatását úgy írták le, mint egy olyan helyzetet, ahol van valaki, akivel meg lehet beszélni a dolgokat, hasonlóak a személyiségjegyeik és érdeklődési körük, valamint vannak közös barátaik. Az önbecsülési támasz ('esteemsupport') elsősorban azt jelentette, hogy a legfontosabb testvér bízik a résztvevő képességeiben és kiállásában saját döntései mellett. Utolsóként a legközelebb álló testvér által nyújtott információs támasz alatt azt az időszakot értették, amikor a testvér az adott pályával kapcsolatos információk forrása volt (pl. munkahelyi információ, tapasztalat, tanács és vélemény).

Néhány résztvevő nem érezte ezt a fajta befolyást a karrierlehetőségek feltérképezésénél, vagy épp a pályaválasztás visszatérő elemmé vált az idősebb testvérrel kapcsolatban (akit egyébként tipikus módon a legfontosabb testvérként azonosítottak).
Másként fogalmazva, a résztvevők úgy érezték, hogy az idősebb testvérek befolyásolták őket. Ugyanakkor azt is hozzátették, hogy ezt nem érezték kölcsönösnek. Azaz nem gondolták úgy, hogy befolyásolták idősebb testvérük pályaorientációját vagy pályaválasztását. a legfontosabb testvérként azonosítottak). Ezek a támasztényezôk általában igen lényegesek az egyén jóléte szempontjából, különösen akkor, ha olyan stresszes élethelyzetekkel kell megküzdenie, mint amilyen például a lehetséges pályák feltérképezése és a pályaválasztás.

\section{A szülői kapcsolatok}

Az értelmiségi és középosztálybeli szülők (akik mindig is nagy jelentőséget tulajdonítottak gyerekeik iskoláztatásának számára) a kilencvenes évek a középfokú iskolakínálat bővülését hozták, amely nagyobb választási lehetőséget nyújt arra, hogy a gyerekeik képességéhez és saját aspirációikhoz legjobban illeszkedő képzési formát (szerkezetváltó gimnázium, két tannyelvű gimnázium, szakközépiskola stb.) válasszák. Az ő szemükben jelenleg az iskolaválasztás legfontosabb szempontja az, hogy melyik középfokú iskola garantálja a legnagyobb valószínűséggel a felsőfokú továbbtanulást (Liskó, 1997).

A szülőkrôl való leválás pszichológiai nehézségei önmagukban még nem okoznak pályaválasztási bizonytalanságot. Mi több, a szülőkhöz füződő kötődési szint önmagában szintén nem jelzi a határozott 
pályaválasztás hiányát. Habár a leválás és a kötődés ilyen irányú hatása külön-külön következmények nélkül áll, a kettő kombinációja adja azt a családi támaszt, ami leginkább elősegíti a pályaválasztási folyamatot.

Blustein és munkatársai (1996) arra a következtetésre jutottak, hogy mindkét változó jelentôs mértékben előmozdítja azt, hogy a pályaválasztás iránti elköteleződés módszerének és folyamatának változatait előre jelezhessük. Ebben az elköteleződési folyamatban a szülőkhöz való kötődés akkor válik fontossá, amikor valamilyen fokú pszichológiai leválasztódással fordul elő egyszerre.

Két fogalmat használnak a leválás definiálására:

- konfliktusos függetlenség

(conflictual independence),

- hozzáállásbeli függetlenség

(attitudinal independence).

A konfliktusos függetlenség a leválás olyan pszichológiai folyamatára utal, ahol hiányzik a bűntudat, a szorongás, a bizalomhiány, a szülők iránt érzett felelősség vagy megbánás. A hozzáállásbeli függetlenség pedig azt jelenti, hogy az egyén olyan attitűdöket, értékeket és elképzeléseket vall magáénak, amelyek különböznek szüleiétől. A leválási-önállósodási folyamat általában tisztázott és stabil identitás kialakulásához vezet. A diszfunkcionálisan múködő családokban a gondolkodás és az érzelmek függetlenségére álta- lában a család integritását veszélyeztető tényezőként tekintenek.

Ezekben a családokban általában nem bátorítják arra a fiatalokat vagy fiatal felnőtteket, hogy kialakítsák a pszichológiai függetlenség érzését. A kötődést pedig úgy definiálhatjuk, mint a kötődés és közelség érzéseinek percepcióját. Blustein és munkatársainak (1996) eredményei a nemek közötti különbségekre mutattak rá. Arra a következtetésre jutottak, hogy azok a nők, akik a szülőkkel szembeni konfliktusos függetlenséget az egyik szülőhöz való mérsékelt kötődéssel együtt élik meg, szintén jobban elkötelezettek pályaválasztásukkal kapcsolatban, és csak kevésbé hajlamosak előre lezártnak tekinteni a pályaválasztást. A kizárás ('foreclosure') azt jelenti, hogy az elköteleződési folyamat iránt zártan, dogmatikusan és kettősséggel viszonyulnak, nem pedig nyitottan. Mindazonáltal nem ez volt a helyzet az ugyanabban a mintában előforduló férfiakkal kapcsolatban, akiknek az esetében nem fedezhetünk fel kapcsolatot a pszichológiai szeparáció és a szülői kötődés között, mely kizárási tendenciával párosulna.

A szerzők arra a következtetésre jutottak, hogy a férfiak elköteleződési folyamata bizonyos fokig az apjukhoz való kötődés és az apjuktól való konfliktusos függetlenség együttes meglétén alapult. Mi több, azok a férfiak, akik viszont nagyobb hozzáállásbeli függetlenséget mutattak az apjuktól, kevésbé voltak elkötelezettek pályaválasztásukkal kapcsolatban. Ennek megfelelően az apáktól való valamilyen 
fokú függés elősegítette a pályaválasztás iránti elkötelezettséget. Az eredmények azt mutatták, hogy az apa-fiú kapcsolat sokkal nagyobb befolyást gyakorol a pályaválasztásra, mint az anya-fiú kapcsolat.

A férfiak és a nők számára egyaránt a bűntudat, a szorongás, a bizalomhiány, valamint a szülő(k) iránt érzett felelősség vagy megbánás hiánya jelentős szerepet töltött be a pályaválasztással kapcsolatos orientációs képességükben. A szülők iránt érzett bizonyos fokú kötődés is közrejátszó tényező volt. A férfiak számára azonban a legfontosabb faktor az apjuk iránti kötődés. A fő különbség az, hogy a férfiak pályaválasztással kapcsolatos elköteleződését elmélyítette az, ha az apjuk attitűdjeihez hasonló nézeteket és értékeket vallottak.

A tanulmány keresztmetszetes szerkezete nem teszi lehetővé az oksági viszonyok vizsgálatát. Az önbeszámoló jellege és felhasználása szintén korlátozó tényező. Továbbá az általánosítást csak olyan, nem végzős diákokra alkalmazhatjuk, akiknek még mind a két szüleje él. Ugyanakkor mindezen korlátok ellenére a kutatók olyan elméleti alapot fektetnek le, amely elősegíti a pályafejlődés megértését a szülők és fiatalok közötti komplex kapcsolati rendszer vizsgálatával.

\section{A családi hálózat}

Számos tanulmány megerősítette már a családi származás egyéni pályafejlődésre és pályaválasztásra gyakorolt befolyását
(Gottfredson, 1971; Palladino, és mtsai, 2002; Super, 1957), de azt a kérdést, hogy a családi dinamika hogyan hat a döntési folyamatra, már jóval ritkábban válaszolták meg a kutatók. (Kinnier és mtsai, 1990) a családi hálózat és pályaválasztási bizonytalanság közötti kapcsolatot vizsgálták. Ezen belül a pályaválasztással kapcsolatos döntésképtelenség mértékét és az önelkülönítés ('self-differentiation') két skáláját (generációk közötti fúzió / egyéni jelleg kialakulása, generációk közötti háromszögelés ['intergenerational fusion' / 'individuation', 'intergenerational triangulation']) vizsgálták a hálózatok ('enmeshment') meghatározsához. A családi dinamikára vonatkozó eredmények azt mutatták, hogy azok, akik határozottabbak voltak, a családjukon belül általában individuálisabbnak tűntek és kevésbé háromszögeltek. Habár az eredmények statisztikailag jelentősek, mindazonáltal gyengék (a teljes ellentmondási mutató 11 százalék). Ez az alkalmazott módszernek köszönhető (mely meglehetősen újnak számított a tanulmány írásakor). Továbbá csekély volt az Egyéni Jelleg Kialakulását Vizsgáló Skála (Individuation Scale) tesztelés-újratesztelés megbízhatósága $(0,55)$, valamint a társadalmilag megkívánttal való pozitív korreláció. Mi több, a tesztalanyok életkorának eloszlása meglehetősen aránytalan volt, mivel a résztvevők életkora 17 és 54 év közé esett, mindazonáltal a megkérdezettek 90 százaléka 24 éven aluli volt. A hálózat és a döntésképtelenség közötti kapcsolatot a jövőben erôsíteni le- 
hetne, ha a hálózat mérésére megfelelőbb mérőeszközt fejlesztenek ki.

A kutatók úgy vélték, hogy a tanulmány készítésének idején ez volt a legalkalmasabb felhasználható eszköz, bár már akkor elismerték, hogy finomítás szükséges. A pályaválasztással kapcsolatos határozatlanság talán a szülők túlzott szerepvállalásában keresendő (családi hálózat vagy fúzió), vagy a háromszögelődésben, ahol mindkét szülő egymásnak ellentmondó információkat ad, melynek következtében az egyén nyomás alatt érzi magát.

\section{A normatív döntéselmélet és az individuális tényezők}

A fentiek szerint az a legjobb döntés, ami leginkább elősegíti a döntéshozó céljainak elérését. Ezeket a célokat az egyén szempontjából megfontolás alatt álló alternatívák különböző tulajdonságai iránt tanúsított preferenciái jelenítik meg. Egy racionális pályaválasztási döntéshozónak úgy kell választania a felmerülő lehetőségek közül, hogy a leghasznosabbat válaszsza. Ebben az értelemben mindegyik alternatíva hasznossága azt a funkciót jelenti, mely az egyéni preferenciák és az alternatíva minden ilyen tényező esetében fennálló tulajdonságai között húzódik. A hasznossági elmélet egy olyan normatív modell, amely a legalkalmasabb döntéshozási módszer előírásaként fogható fel (Baron, 1988; Brown, 1990).

A pályaválasztásnak a következő jellemzői vannak:
- adott egy egyén, akinek döntésre kell jutnia,

- van egy bizonyos számú alternatíva, melyek közül választhat,

- valamint számos olyan jellemző vagy aspektus, amelyeket a különféle alternatívák értékelése és összevetése révén mérlegel.

E számos döntési helyzetre kiterjeszthető tulajdonsághalmazon kívül a pályaválasztás rendelkezik néhány csak rá jellemző adottsággal. Először is, a lehetséges alternatívák köre meglehetősen széles (pl. a különböző foglalkozások, főiskolák, szakok, vagy potenciális munkaadók száma). Másodsorban igen nagy mennyiségú információ áll rendelkezésre mindegyik alternatívával kapcsolatban. Harmadrészt, igen sok tényező ismeretére (pl. a képzés hossza, a függés mértéke, az emberekkel fenntartott kapcsolat típusa) van szükség ahhoz, hogy megfelelőképpen és részletesen jellemezni lehessen a foglalkozásokat és az egyén preferenciáit úgy, hogy még érthető legyen (pl. Gati, Garty, \& Fassa, 1996). Negyedrészt pedig a bizonytalanság, amely igen nagy szerepet játszik az egyén tulajdonságaival (pl. jelenbeli és jövőbeni preferenciák), valamint a jövőbeni pályaalternatívák jellegével kapcsolatban.

Az ember életpályája során számtalanszor kerülhet olyan belyzetbe, hogy akár személyes fejlödése, akár a külsö körülmények változása miatt változtatni kényszerül, esetleg üj sqakmát kell elsajátitania, hiszen lehetséges, hogy tíz vagy hüsz év múlva az, ami most érdekeli, ami most fontos, jelentöségét vesżti, és más válike lényegessé 
számára. Másrész̨t külső okok is közbejöhetnek, hiszen a gazdasági és a munkaerō piaci helyzet változásai is érinthetik a karriert (Bandura, 1994).

A hivatás kiválasztásában számos belső és külső faktor egyaránt befolyásolja az egyént. Azokat az endogén változókat, amelyek gyakori előfordulásukkal hatnak az egyén életére, pszichológiai, belső faktoroknak nevezzük.

A pályaválasztásban közrejátszó főbb endogén pszichológiai tényezők az alábbiak: motiváció, érzelmi intelligencia és maga az ember személyiségtípusa.

Külső tényezők fogalma alatt a szociális faktorokat értjük. Fontos szerepet töltenek be, és erősen befolyásolják az egyént döntéseinek meghozatala során. A föbb külső faktorok esetén az alábbiakról tehetünk említést: család, baráti társaság, iskola stb.

A család hatása tehát meghatározó. És nem csupán a családdal való interakció mentén, de mint kontextus, mint értéket, normát, szerepeket közvetítő közeg is jelentős, amellyel lehet akár azonosulni, akár attól távolságot tartani. Tehát a szerepe nem csupán a pályairány kijelölésében, de a későbbi munkavállalásban is jelentős. A fiatal pályafejlődésére igazolhatóan két családi tényező hat (Whiston és Keller 2004). Gondolhatunk itt a családi kapcsolatok közelségére-távolságára, a szülők részvételére a gyermek iskolai életében, a konkrét támogatásra, vagy arra, hogy milyenek a pályával szembeni családi elvárások. Jelentős lehet a szülők aktív segítsége a pályafejlődés érdekében, mint például a tájékozódás, tervezés, speciális információk szerzése (Lindstrom, és tsai, 2007).

A pályaválasztási bizonytalanság olyan fejlődési sajátosság, amin a személyek keresztülmennek a döntéshozatal előtt, miközben a számukra legmegfelelőbb alternatívát keresik. A pályaválasztási bizonytalanság kognitív és érzelmi elemeket is magában foglal. A kognitív komponensek közé soroljuk a célállást, pályacél hiányát, az önismeret hiányosságait, a környezettel kapcsolatos ismeretek hiányát, és a munka-erőpiaci változások elfogadásának hiányát (Osipow, 1999).

A bizonytalanság olyan időleges állapot, ami a döntéshozatal előtt, vagy olyankor jelenik meg, ha egy korábbi döntés elavulttá válik, és új döntést kell hozni a pályával kapcsolatban. Ennek értelmében a fejlődés során megjelenő normatív állapotnak tekintjük. Az, hogy középiskolás korban a személy bizonytalan, egyáltalán nem jelenti azt, hogy a későbbiekben ne lenne képes akár az egész életpályáját meghatározó elköteleződésre valamely foglalkozás, szakma mellett. Feltehetőleg, ahogy halad előre az életpályájában a személy, egyre ritkábban kényszerül pályamódosításra, ezért a pályaválasztási bizonytalanság állapotának megjelenése is ritkul. Azonban az első pályaválasztás előtti bizonytalanság megjelenésével a legtöbb középiskolás esetében számolnunk kell. 


\section{Következtetések}

Nagy lehetőséget rejt magában és sokat lehet majd tanulni abból, ha megértjük, hogy az egyének hogyan tanulnak és készülnek fel a munkára. Ismert tény, hogy néhány fiatal felnőtt a testvéreitől tanul azáltal, hogy információs forrásként használja őket (azaz információs támasznak). A testvéreikhez fordulnak tanácsért és véleményért, valamint őket tekintik példaképnek is. Ahhoz, hogy a pályaválasztási tanácsadóhoz fordulók pályaválasztási problémáit megfelelőképp diagnosztizálni lehessen, minden szükséges segítséget meg kell adni számukra (habár természetesen ez nem minden).

Amint már korábban említésre került, a pályaválasztási nehézségekre ki lehetne dolgozni és tesztelni lehetne egy elméleti keretet. Ha megismernénk, hogy az egyének hogyan internalizálják a testvérektől szerzett információt a munkáról kialakított személyes képekké és elvárásokká, akkor sokkal jobban fel tudnánk készülni az intervencióra.

További szisztematikus kvantitatív tanulmányokra van szükség annak kiértékeléséhez, hogy a testvéri támogatás és a testvérrel való azonosulás milyen mértékben áll összefüggésben a lehetséges pályák feltérképezésének sikerességével, a pályaválasztás iránti elköteleződés felé megtett lépésekkel, az elérni kíván munkahelyi célokkal és a jövőbeni munkavégzéssel kapcsolatos elvárásokkal.

A viselkedés megfigyelését fel lehet használni arra, hogy kvantitatív módon megmérjük a családi környezet és a fiatal felnőttek karrierfejlődésének és pályaelégedettségének sikeres megtárgyalása közötti kapcsolatot.

A szülők társadalmi helyzete és iskolázottsága mindig is meghatározta a gyerekek pályaválasztási aspirációit és az elképzelések megvalósulásának esélyét. $1997-$ ben is azt tapasztaltuk, hogy minél magasabb iskolázottsággal rendelkeznek a szülők, annál valószínúbb, hogy gyerekeik valamelyik jó hírū gimnáziumba jelentkeznek, és ugyancsak nagy valószínűséggel fel is veszik őket. A gazdasági és társadalmi átalakulás nemcsak a gyerekek, hanem a szülők elképzeléseit is elbizonytalanította. A konkrét foglalkozást illető bizonytalanság a magasan iskolázott szülőket jellemezte leginkább, ami arra utal, hogy ezek a szülők nemcsak a gyerekeiknek szánnának több időt a pályaválasztási döntés érlelésére, hanem saját maguk sem vállalnak túl korai, elhamarkodott döntéseket.

A kutatás hiányos továbbá a tekintetben is, hogy más kontextuális tényezők (például: szociokulturális és szocio-ökonómiai) hogyan viszonyulnak a karrierfejlődéshez és a pályaválasztáshoz.

\section{Köszönetnyilvánítás}

A Szerző köszönetét fejezi ki az EFOP3.6.1-16-2016-00001 kódszámú pályázati támogatásért! 


\section{Irodalom}

Blustein, D. L., Walbridge, M. M., Friedlander, M. L. és Palladino, D. E., (1996): Contributions of psychological separation and parental attachment to the career developmental process. Journal of Counseling Psychology, 38. 1. sz. pp. 39-50. doi: 10.1037/0022$\underline{0167.38 .1 .39}$

Breban, D., (2010): Psychological Implication of Career Decision Process. Babes-Bolyai University The School of Psychology and Educational Science.

Chartrand, J. M., Robbins, S. B., Morril, W., (1990): Development and validation of the Career Factors Inventory. Journal of Counseling Psychology, 37, p.491- 501.

Cicirelli, V.G., (1995): Sibling Relationships Across the Lifespan. Plenum, New York. doi: $\underline{\text { 10.1007/978-1-4757-6509-0 }}$

Csákó, M., (1998): Szakirányú továbbtanulás. Educatio, 3. sz. p. 470-486

Földes, P., (2000): A család és az iskola együttmúködése. Új Pedagógiai Szemle, 11., pp. 130-134.

Gati, I., (2013): Advances incareer decision making. In B. W. Walsh, M. L. Savickas, \& P. J. Hartung (Eds.), Handbook of vocational psychology: Theory, research and practice pp. 183-215. New York, NY: Routledge.

Gati, I., Amir, T., (2006): Facets of career decision-making difficulties. British Journal of Guidance \& Counselling, Vol. 34, No. 4, pp. 484-502.
Gati, I., Krausz, M., \& Osipow, S.H., (1996): A taxonomy of difficulties in career decision-making. Journal of Counseling Psychology, 43, pp. 510-526.

Gati, I., \& Levin, N., (2014): Making better careerdecisions. In P. J. Hartung, M. L. Savickas, \& B. W. Walsh (Eds.), Handbook of careerintervention (Vol. 2, pp. 193-207). Washington, DC: American Psychological Association. doi: $10.1037 / 14439-015$

Gati, I., \& Perez, M., (2014): Gender differences in career preferences from 1990 to 2010: Gaps reduced but not eliminated. Journal of Counseling Psychology, 61, 63-80. doi: $\underline{10.1037 / \mathrm{a} 0034598}$

Guay, F., Senecal, C., Gauthier, L. és Fernet, C., (2003): Predicting careerin decision: A self-determination theory perspective, Journal of Counseling Psychology, 50. 2. sz. pp. 165-177. doi: 10.1037/0022-0167.50.2.165

Judy, M., Chartrand, Kevin, J., Nutter (1996): The Career Factors Inventory: Theory and Applications Jurnal of Carrier Asessment Vol. 4, Nr.2 , p.:205218.

Kissné Viszket, M. és Mogyorósy-Révész Zs. (2017): Pszichológiai tanácsadás szakmai alapprotokoll - a tanácsadói folyamat. Alkalmazott pszichológia, 2017, 17(4):45-66 doi:

10.17627/ALKPSZICH.2017.4.45

L Boreham, J., (1967): The Psycho-dynamic Diagnosis and Treatment of 
Vocational Problems. The British Journal of Social and Clinicalpsychology. 6. 1508. doi: 10.1111/j.2044-8260.1967.tb00513.x

Leong, F. T. L., és Chervinko, S., (1996): Constructvalidity of careerindecision: Negative personality traits as predictors of careerindecision. Journal of Care Assessment, 4. sz. 315-329. doi: $10.1177 / 106907279600400306$

Liskó, I., (1997): Hátrányos helyzetű gyerekek a szakképző iskolákban. Educatio, 6. 1. sz. 60-73.

Maree, J. G. (2013): Counselling for career construction: Connecting life themes to construct life portraits: Turning pain in to hope. Rotterdam, The Netherlands: Sense Publisher.

Mau, W. C. (1995): Decision-making style as a predictor of career decision making status and treatment gains. Journal of Career Assessment, 3. sz. 8999. doi: $10.1177 / 106907279500300107$

Mező, F. és Mező, K. (2019): Az OxIPOmodell - Az interdiszciplináris kutatások egy lehetséges értelmezési kerete. OxIPO - interdiszciplináris e-folyóirat, 1 (1). pp. 9-21. doi: 10.35405/OXIPO.2019.1.9

Olteanu, L.L., (2015): A pályaválasztás rendszerelméleti nézőpontból, Iskolakultura, 25. évfolyam, 2015/9. szám doi: 10.17543/ISKKULT.2015.9.45

Olteanu, L.L., (2019): A pályaválasztás során fellépő döntéshozási nehézségek. OxIPO - interdiszciplináris tudomá- nyos folyóirat, 2019/1, 53-59. doi: 10.35405/OXIPO.2019.1.53

Osipow, S. H., (1997): RoeRevisited: Why? Journal of Vocational Behavior. 51, p. 306-309.

Palladino Schultheiss, D. E., Palma, T. V., Predragovich, K. S. \& Glasscock, J. M. (2002): Relational influences on career paths: Siblings in context. Journal of Counseling Psychology, 49. 3. sz. 302-310. doi: 10.1037/0022-0167.49.3.302

Papp, P. és Imber-Black, E., (1996): Family themes: Transmissions and transformation. Family Process, 35.sz. 5-20. doi: 10.1111/j.1545-5300.1996.00005.x

Perry, J. C., Liu, X., \& Pabian. Y. (2010). School engagement as a mediator of academic performance among urban youth: The role of career preparation, parental career support, and teacher support. The Counseling Psychologist 38 (2),269-295. doi: $10.1177 / 0011000009349272$

Ritoókné, Á. M., (szerk.) (2002): A tanácsadás pszichológiája, szöveggyüjtemény. Nemzeti Tankönyvkiadó, Budapest.

Ritoók, P., (2006): Pályalélektan, a pályaválasztás pszichológiája. Bagdy E. és Klein S. (szerk.): Alkalmazott Pszichológia. Edge 2000, Budapest. 50-65.

Rounds, J. B., \& Tinsley, H. E. A., (1984): Diagnosis and treatment of vocational problems. In S. D. Brown \& R. W. Lent (Eds.), Handbook of counseling psychology. New York: Wiley. pp. $137-$ 177 
Tinsley, H. E. A., (1992): Career decision making and careerindecision. Journal of Vocational Behavior, 41, 209-211.

Walsh W.B., Osipow S.H., (1988): Career Decision-making. Hillsdale, NJ: Laurence Erlbaum Associates.
Whiston, S. C. (1996): The relationship among family interaction patterns and careerindecision and careerindecisionmaking selfefficacy. Journal of Career Development, 23. sz. 137-149. doi: $\underline{10.1007 / \mathrm{bf} 02359293}$ 